\title{
HOSTING CAPACITY OF HORTICULTURAL PLANTS FOR INSECT PESTS IN BRAZIL
}

\author{
Germano L.D. Leite ${ }^{1 *}$, Marcelo Picanço², José C. Zanuncio², Márcio D. Moreira², and Gulab N. Jham ${ }^{3}$
}

Factors such as fertilization, allelochemicals, trichomes, weather, and natural enemies can influence pest populations. Thus, it is necessary to understand the factors that predispose vegetable species to pests and the role of polyculture, crop rotation, and neighboring plants. The objective of this research was to study the hosting capacity for pests of Abelmoschus esculentus (L.), Brassica oleracea L. vars. acephala and capitata, Capsicum annuum L., Cucurbita moschata (Duchesne), Cucurbita maxima Duchesne and Cucumis sativus L., Lycopersicon esculentum Mill., Solanum gilo Raddi and Solanum melongena L., and Phaseolus vulgaris L. The higher density of Bemisia tabaci (Genn.) adults on C. sativus can be due to the higher amount of pentacosane and octacosane in this plant. The occurrence of Brevicoryne brassicae (L.) only in Brassica spp. can be accounted for by the nonacosane of these plants. The low trichome density and greater palmitic acid level can explain the greatest damage by Aphis gossypii Glover in A. esculentum. Empoasca sp. was more frequent in $P$. vulgaris followed by A. esculentum, which are plants with lower K content. Solanum melongena was attacked more by Hydrangea similis (Walker) and Epitrix sp. perhaps because of higher palmitic acid and 11,14,17-eicosatrienoic methyl ester concentrations in their leaves. Frankliniella sp. exhibited more damage in C. sativus probably owing to higher pentacosane and octacosane in its leaves. Sistena sp. was more frequent in C. maxima and had higher octadecane levels and trichome density. The presence of $\infty$-humulene and hexacosane can explain the damage by Tuta absoluta (Meyrick) on L. esculentum.

Key words: Trichomes, allelochemicals, nitrogen, potassium, insects.

$\mathrm{C}$ ultivated plants are attacked by insect pests in the absence of culture rotation with non-host plants, use of insecticides, and chemical fertilizers especially in monocultures. This facilitates the attack of insect pests and reduces natural biological control to make larger amounts of nutrients available for these plants (Gallo et al., 2002; Altieri et al., 2003).

Factors such as fertilization (Slosser et al., 2004; Chau et al., 2005), allelochemicals, trichomes, weather, and natural enemies can influence pest populations (Sechser et al., 2002; Men et al., 2004; Rhainds and Messing, 2005; Satar et al., 2005). An N excess or K deficiency can lead to higher accumulations of amino acids which in turn can cause higher attack rates by sucking insects (Jansson and Ekbom, 2002). The high nonacosane level can regulate aphid populations on kale given its high level in this vegetable. The general hypothesis is that wax rarely detains herbivore attack and commonly stimulates it (Woodhead and Chapman, 1986; Leite et al., 2005c).

${ }^{1}$ Universidade Federal de Minas Gerais/Instituto de Ciências Agrárias, Caixa Postal 135, CEP 39404-006, Montes Claros, Minas Gerais, Brasil. *Corresponding author (gldleite@ig.com.br).

${ }^{2}$ Universidade Federal de Viçosa (UFV), Departamento de Biologia Animal, CEP 36571-000, Viçosa, Minas Gerais, Brasil.

${ }^{3}$ Universidade Federal de Viçosa (UFV), Departamento de Química, CEP 36571-000, Viçosa, Minas Gerais, Brasil.

Received: 26 November 2010.

Accepted: 30 March 2011.
Trichomes can affect insect locomotion, feeding, and reproduction both positively and negatively, depending on the type of trichome, plant, and insect involved (Gallo et al., 2002). High rainfall is an important mortality factor for some insects in the field (Rhainds and Messing, 2005), as well as natural enemies such as parasitoids of the Braconidae family (Rhainds and Messing, 2005), spiders, ladybird beetles (Men et al., 2004), and aphid Syrphidae larva (Sechser et al., 2002).

It is therefore necessary to understand the factors that predispose horticultural species to pests and the role of polyculture, crop rotation, and neighboring plants (Brunner et al., 2004).

Leaf $\mathrm{N}$ and $\mathrm{K}$ levels, allelochemicals, trichomes (type and density), natural enemy and pest populations, and weather effect on the main vegetables cultivated in Brazil, such as Abelmoschus esculentus (L.) Moench (Malvaceae), Brassica oleracea L. vars. acephala and capitata (Brassicaceae), Capsicum annuum L. (Solanaceae), Cucurbita moschata (Duchesne), C. maxima Duchesne and Cucumis sativus L. (Cucurbitaceae), Lycopersicon esculentum Mill., Solanum gilo Raddi and S. melongena L. (Solanaceae), and Phaseolus vulgaris L. (Fabaceae), have been studied (Leite et al., 2001a; 2001b; 2002a; 2002b; 2002c; 2003; 2005a; 2005b; 2005c; 2006a; 2011) with the objective of comparing host capacity of those plants for insect pests, the relationships of these pests with their morphologic, nutritional, and chemical features, 
their natural enemies, and weather conditions in order to propose crop rotation and management procedures of neighboring plants to reduce insect damage.

\section{MATERIALS AND METHODS}

Four okra crops (A. esculentus (L.) var. Santa Cruz), kale (B. oleracea (L.) var. acephala genotype Talo roxo), cabbage (B. oleracea (L.) var. capitata var. Saturno), sweet pepper ( $C$. annuum L. var. Myr-10), pumpkin $(C$. moschata (Duchesne) var. Menina brasileira), winter squash (C. maxima Duchesne var. IAC-100), cucumber (C. sativus L. var. Joia Agroceres), tomato (L. esculentum Mill. var. Santa Clara), gilo (S. gilo Raddi var. Gigante português), eggplant ( $S$. melongena L. var. Natu Nobilis), and common bean (P. vulgaris L. var. Nekito) were studied in the municipalities of Viçosa (20 44'38.7' S, 42 49' 18.7' W, $649 \mathrm{~m}$ a.s.1.) (two crops) and Guidoval $\left(21^{\circ} 08^{\prime} 36^{\prime \prime} \mathrm{S}\right.$, 42 47'54" W, 239 m a.s.1.) (two crops), Minas Gerais, Brazil from October 1998 to December 1999.

The design was completely randomized with four replicates (crops). The four outermost rows in every plot and the first 15 plants on each side of the rows formed the surrounding border, and data were collected on plants in the center of each plot. Fertilization, agronomic practices, spacing between plants and rows have been described for these plants (Filgueira, 2000); moreover, no insecticides were sprayed.

Pests and predators were counted monthly in the municipality of Guidoval and weekly in the municipality of Viçosa. Insects were counted visually on one expanded leaf from each of three canopy strata, i.e., bottom, medium, and apical ( 0 to 33,33 to 66 , and 66 to $100 \%$ of total plant height, respectively) of 10 plants per crop (three leaves per plant) (Horowitz, 1993). The number of adult parasitoids was estimated with the beating tray method on one leaf from each of 10 plants per plantation (Miranda et al., 1998) on a monthly basis in Guidoval and weekly in Viçosa. This method consisted of beating and counting the insects in the first fully expanded leaf in a $34 \times 26 \times 5 \mathrm{~cm}$ white tray. The insects dislodged onto the tray were collected with an aspirator or tweezers and individualized in $8 \times 2 \mathrm{~cm}$ vials with $70 \%$ ethanol.

Trichome density was determined on one expanded leaf from the apical, medium, and bottom canopy strata of 10 plants per crop (three leaves per plant), which were collected monthly in Guidoval and Viçosa, prepared on slides, and the trichome assessed (Leite et al., 2001a; 2001b; 2002a; 2002b; 2002c; 2003; 2005a; 2005b; 2005c; 2006a; 2011). Leaf $\mathrm{N}$ and $\mathrm{K}$ levels were determined monthly in the laboratory from one expanded leaf of the upper parts of 10 plants per crop in both municipalities. These leaves were dried and ground, $\mathrm{K}$ was determined with a flame photometer, and $\mathrm{N}$ analyzed by the Nessler method. Fully expanded apical leaves of 10 plants per crop were sampled monthly in both municipalities by gas chromatography/mass spectrometry (GC/MS) and hexane analyses were performed as in Leite et al . (2001a; 2001b; 2002a; 2002b; 2002c; 2003; 2005a; 2005b; 2005c; 2006a, 2011). Morphological, nutritional, and chemical analyses were made with three independent monthly evaluations for each plantation.

Guidoval weather data (rainfall and temperature) were obtained daily, and Viçosa data came from the "Estação Climatológica Principal" of the Federal University of Viçosa (UFV) (INMET $\left./ 5^{\circ} \mathrm{DISME} / \mathrm{UFV}\right)$. Weather data were not normally distributed. Density of pests, natural enemies, trichomes, leaf $\mathrm{N}$ and $\mathrm{K}$, as well as organic compound levels were subjected to ANOVA, the ScottKnott test employing transformed data $(\sqrt{ } \mathrm{x}+0.5)$, and Spearman's correlation. The significance level was $5 \%$ in all the tests.

\section{RESULTS}

The number of Bemisia tabaci (Genn.) (Aleyrodidae) adults were higher in cucumber and eggplant. Brevicoryne brassicae (L.), found only in kale and cabbage, had larger populations on the former, whereas Myzus persicae (Sulzer) had a higher number of individuals on tomato, and was also found on Solanum gilo and sweet pepper. Aphis gossypii Glover was found on okra, pumpkin, winter squash, eggplant, and cucumber with higher numbers on the first plant. Aphis crassivora Koch (Aphididae) was found only on common bean and Empoasca spp. had higher populations in this crop, although it was collected on most vegetable species, except kale and winter squash. Hydrangea similis (Walker) (Cicadellidae) was found on eggplant, and also in lower numbers on kale, cabbage, sweet pepper, common bean, gilo, tomato, and okra (Table 1).

Four thrips species (Thysanoptera: Thripidae) were found. Thrips palmi Karny was found on eggplant; Thrips tabaci Lind. on Brassica spp. and with higher numbers in kale; Caliothrips brasiliense (Morgan), only on common bean; and Frankliniella sp. on cucumber, gilo, pumpkin, winter squash, sweet pepper, okra, and tomato (Table 1).

The main defoliator beetles (Coleoptera: Chrysomelidae) were Epitrix sp. on eggplant, pumpkin, common bean, gilo, sweet pepper, tomato, and okra; Sistena sp. on winter squash, and in small numbers on pumpkin, kale, cabbage, tomato, gilo, sweet pepper, and common bean (Table 1). Other Chrysomelidae included Diabrotica speciosa (Germ.) on pumpkin, eggplant, common bean, gilo, sweet pepper, okra, and tomato; Colaspis sp. on pumpkin, eggplant, common bean, gilo, cucumber, sweet pepper, and okra; Acalina sp. on pumpkin; Cerotoma sp. on eggplant, common bean, gilo, and sweet pepper; and Epicauta sp. (Meloidae) on eggplant and sweet pepper (Table 1).

Tuta absoluta (Meyrick) (Lepidoptera: Gelechiidae) was found on tomato and Liryomiza sp. (Diptera: 
Table 1. Density of herbivorous insects/leaf in some crops. Municipalities of Guidoval and Viçosa, Minas Gerais, Brazil.

\begin{tabular}{|c|c|c|c|c|c|c|c|c|c|c|c|}
\hline Insects & Pumpkin & Eggplant & Kale & Bean & Gilo & $\begin{array}{l}\text { Winter } \\
\text { squash }\end{array}$ & Cucumber & $\begin{array}{l}\text { Sweet } \\
\text { pepper }\end{array}$ & Okra & Cabbage & Tomato \\
\hline Bemisia tabaci & $0.42 \mathrm{~B}$ & $12.82 \mathrm{~A}$ & $0.19 \mathrm{~B}$ & $0.82 \mathrm{~B}$ & $1.91 \mathrm{~B}$ & $0.38 \mathrm{~B}$ & $19.31 \mathrm{~A}$ & $0.16 \mathrm{~B}$ & $2.23 \mathrm{~B}$ & $0.17 \mathrm{~B}$ & $8.13 \mathrm{~B}$ \\
\hline Brevicoryne brassicae & $0.00 \mathrm{~B}$ & $0.00 \mathrm{~B}$ & $0.92 \mathrm{~A}$ & $0.00 \mathrm{~B}$ & $0.00 \mathrm{~B}$ & $0.00 \mathrm{~B}$ & $0.00 \mathrm{~B}$ & $0.00 \mathrm{~B}$ & $0.00 \mathrm{~B}$ & $0.51 \mathrm{~A}$ & $0.00 \mathrm{~B}$ \\
\hline Myzus persicae & $0.00 \mathrm{~B}$ & $0.00 \mathrm{~B}$ & $0.00 \mathrm{~B}$ & $0.00 \mathrm{~B}$ & $0.29 \mathrm{~B}$ & $0.00 \mathrm{~B}$ & $0.00 \mathrm{~B}$ & $0.12 \mathrm{~B}$ & $0.00 \mathrm{~B}$ & $0.00 \mathrm{~B}$ & $1.72 \mathrm{~A}$ \\
\hline Aphis gossypii & $0.06 \mathrm{~B}$ & $0.39 \mathrm{~B}$ & $0.00 \mathrm{~B}$ & $0.00 \mathrm{~B}$ & $0.00 \mathrm{~B}$ & $0.18 \mathrm{~B}$ & $0.06 \mathrm{~B}$ & $0.00 \mathrm{~B}$ & $5.55 \mathrm{~A}$ & $0.00 \mathrm{~B}$ & $0.00 \mathrm{~B}$ \\
\hline Aphis craccivora ${ }^{*}$ & 0.00 & 0.00 & 0.00 & 0.11 & 0.00 & 0.00 & 0.00 & 0.00 & 0.00 & 0.00 & 0.00 \\
\hline Empoasca spp. & $0.01 \mathrm{~B}$ & $0.03 \mathrm{~B}$ & $0.00 \mathrm{~B}$ & $1.39 \mathrm{~A}$ & $0.04 \mathrm{~B}$ & $0.00 \mathrm{~B}$ & $0.02 \mathrm{~B}$ & $0.05 \mathrm{~B}$ & $0.39 \mathrm{~B}$ & $0.01 \mathrm{~B}$ & $0.0004 \mathrm{~B}$ \\
\hline Hortensia similis & $0.00 \mathrm{~B}$ & $0.12 \mathrm{~A}$ & $0.003 \mathrm{~B}$ & $0.01 \mathrm{~B}$ & $0.01 \mathrm{~B}$ & $0.00 \mathrm{~B}$ & $0.00 \mathrm{~B}$ & $0.001 \mathrm{~B}$ & $0.01 \mathrm{~B}$ & $0.002 \mathrm{~B}$ & $0.001 \mathrm{~B}$ \\
\hline Thrips palmi & 0.00 & 0.61 & 0.00 & 0.00 & 0.00 & 0.00 & 0.00 & 0.00 & 0.00 & 0.00 & 0.00 \\
\hline Thrips tabaci & $0.00 \mathrm{~B}$ & $0.00 \mathrm{~B}$ & $4.82 \mathrm{~A}$ & $0.00 \mathrm{~B}$ & $0.00 \mathrm{~B}$ & $0.00 \mathrm{~B}$ & $0.00 \mathrm{~B}$ & $0.00 \mathrm{~B}$ & $0.00 \mathrm{~B}$ & $3.00 \mathrm{~A}$ & $0.00 \mathrm{~B}$ \\
\hline Frankliniella sp. & $0.17 \mathrm{C}$ & $0.001 \mathrm{C}$ & $0.00 \mathrm{C}$ & $0.00 \mathrm{C}$ & $1.98 \mathrm{~B}$ & $0.46 \mathrm{C}$ & $5.58 \mathrm{~A}$ & $0.19 \mathrm{C}$ & $0.73 \mathrm{C}$ & $0.00 \mathrm{C}$ & $0.20 \mathrm{C}$ \\
\hline Caliothrips brasiliense & $0.00 \mathrm{~B}$ & $0.00 \mathrm{~B}$ & $0.00 \mathrm{~B}$ & $9.12 \mathrm{~A}$ & $0.00 \mathrm{~B}$ & $0.00 \mathrm{~B}$ & $0.00 \mathrm{~B}$ & $0.00 \mathrm{~B}$ & $0.00 \mathrm{~B}$ & $0.00 \mathrm{~B}$ & $0.00 \mathrm{~B}$ \\
\hline Epitrix sp. & $0.01 \mathrm{~B}$ & $0.78 \mathrm{~A}$ & $0.00 \mathrm{~B}$ & $0.01 \mathrm{~B}$ & $0.02 \mathrm{~B}$ & $0.00 \mathrm{~B}$ & $0.00 \mathrm{~B}$ & $0.06 \mathrm{~B}$ & $0.01 \mathrm{~B}$ & $0.00 \mathrm{~B}$ & $0.0007 \mathrm{~B}$ \\
\hline Sistena $\mathrm{sp}$ & $0.01 \mathrm{~B}$ & $0.00 \mathrm{~B}$ & $0.002 \mathrm{~B}$ & $0.01 \mathrm{~B}$ & $0.002 \mathrm{~B}$ & $0.15 \mathrm{~A}$ & $0.00 \mathrm{~B}$ & $0.003 \mathrm{~B}$ & $0.00 \mathrm{~B}$ & $0.002 \mathrm{~B}$ & $0.0004 \mathrm{~B}$ \\
\hline Diabrotica speciosa* & 0.0042 & 0.0029 & 0.0000 & 0.0164 & 0.0075 & 0.0000 & 0.0000 & 0.0105 & 0.0088 & 0.0000 & 0.0029 \\
\hline Colaspis sp.* & 0.0417 & 0.0606 & 0.0000 & 0.0143 & 0.0015 & 0.0000 & 0.0042 & 0.0024 & 0.0471 & 0.0000 & 0.0000 \\
\hline Acalina sp.* & 0.0333 & 0.0000 & 0.0000 & 0.0000 & 0.0000 & 0.0000 & 0.0000 & 0.0000 & 0.0000 & 0.0000 & 0.0000 \\
\hline Cerotoma sp.* & 0.0000 & 0.0029 & 0.0000 & 0.0071 & 0.0050 & 0.0000 & 0.0000 & 0.0048 & 0.0000 & 0.0000 & 0.0000 \\
\hline Epicauta sp.* & 0.0000 & 0.0600 & 0.0000 & 0.0000 & 0.0000 & 0.0000 & 0.0000 & 0.0020 & 0.0000 & 0.0000 & 0.0000 \\
\hline Liryomiza sp.* & 0.0033 & 0.0018 & 0.0027 & 0.0020 & 0.0045 & 0.0001 & 0.0167 & 0.0000 & 0.0118 & 0.0077 & 0.0025 \\
\hline Tuta absoluta* & 0.00 & 0.00 & 0.00 & 0.00 & 0.00 & 0.00 & 0.00 & 0.00 & 0.00 & 0.00 & 0.41 \\
\hline
\end{tabular}

Means in a row with the same upper case letter do not differ according to Scott-Knott test $(\mathrm{P}<0.05)$. Not different by ANOVA.

Agromyzidae) on most plants, except winter squash and sweet pepper (Table 1).

The most frequent parasitoids were Adialytus sp. (Hymenoptera: Braconidae) (aphid parasitoid) and Encarsia sp. (whitefly parasitoid) (Hymenoptera: Aphelinidae), found mainly on okra (Table 2). The most common predators were Syrphus sp. (Diptera: Syrphidae) and the Cycloneda sanguine (L.), Eriops connexa Germar, Scymnus sp. and Exochomus bimaculosus Mulsant (Coleoptera: Coccinellidae) ladybugs, found mainly on okra (Table 2). Other predators were spiders [Architis sp. (Pisauridae), Cheiracanthium inclusum
(Hentz) (Miturgidae), Dictyna sp. (Dictynidae), Eustala sp. (Araneidae), Latrodectus geometricus (Koch) (Theridiidae), Lyssomanes sp. (Salticidae), Oxyopes sp. (Oxyopidae), Misumenops spp. (Thomisidae) and Anyphaenidae (Table 2)].

Trichomes of the crop plants were mostly nonglandular, except common bean (68\% non-glandular) with higher densities on tomato followed by winter squash, pumpkin, common bean, gilo, eggplant, and cucumber (Table 3). The highest $\mathrm{N}$ levels were found in the leaves of pumpkin, gilo, and winter squash, as well as $\mathrm{K}$ on sweet pepper (Table 3).

Table 2 . Density of natural enemies and associated ants/leaf in some plant crops. Municipalities of Guidoval and Viçosa, Minas Gerais, Brazil.

\begin{tabular}{|c|c|c|c|c|c|c|c|c|c|c|c|}
\hline Insects & Pumpkin & Eggplant & Kale & Bean & Gilo & $\begin{array}{l}\text { Winter } \\
\text { squash }\end{array}$ & Cucumber & $\begin{array}{l}\text { Sweet } \\
\text { pepper }\end{array}$ & Okra & Cabbage & Tomato \\
\hline Adialytus sp. & $0.01 \mathrm{~B}$ & $0.10 \mathrm{~B}$ & $0.13 \mathrm{~B}$ & $0.06 \mathrm{~B}$ & $0.05 \mathrm{~B}$ & $0.00 \mathrm{~B}$ & $0.03 \mathrm{~B}$ & $0.05 \mathrm{~B}$ & $0.45 \mathrm{~A}$ & $0.07 \mathrm{~B}$ & $0.01 \mathrm{~B}$ \\
\hline Encarsia sp. & $0.02 \mathrm{~B}$ & $0.01 \mathrm{~B}$ & $0.00 \mathrm{~B}$ & $0.03 \mathrm{~B}$ & $0.01 \mathrm{~B}$ & $0.08 \mathrm{~B}$ & $0.08 \mathrm{~B}$ & $0.00 \mathrm{~B}$ & $0.26 \mathrm{~A}$ & $0.01 \mathrm{~B}$ & $0.01 \mathrm{~B}$ \\
\hline Trichogramma sp.* & 0.0167 & 0.0000 & 0.0100 & 0.0057 & 0.0120 & 0.0750 & 0.0291 & 0.0229 & 0.0077 & 0.0039 & 0.0414 \\
\hline Scelionidae* & 0.0040 & 0.0000 & 0.0000 & 0.0000 & 0.0000 & 0.0000 & 0.0167 & 0.0033 & 0.0036 & 0.0000 & 0.0000 \\
\hline Eulophidae* & 0.0040 & 0.0600 & 0.0000 & 0.0300 & 0.0000 & 0.0130 & 0.0142 & 0.0000 & 0.0082 & 0.0300 & 0.0300 \\
\hline Pteromalidae* & 0.0180 & 0.0194 & 0.0000 & 0.0000 & 0.0220 & 0.0250 & 0.0000 & 0.0467 & 0.0000 & 0.0000 & 0.0039 \\
\hline Encyrtidae* & 0.0000 & 0.0000 & 0.0082 & 0.0200 & 0.0000 & 0.0000 & 0.0000 & 0.0048 & 0.0000 & 0.0000 & 0.0093 \\
\hline Eucoilidae $^{*}$ & 0.0140 & 0.0000 & 0.0036 & 0.0500 & 0.0000 & 0.0750 & 0.0125 & 0.0476 & 0.0000 & 0.0000 & 0.0043 \\
\hline Mymaridae* & 0.0000 & 0.0000 & 0.0000 & 0.0000 & 0.0480 & 0.0000 & 0.0000 & 0.0000 & 0.0000 & 0.0000 & 0.0000 \\
\hline Platygastridae & 0.0210 & 0.0000 & 0.0000 & 0.0000 & 0.0020 & 0.0000 & 0.0000 & 0.0033 & 0.0000 & 0.0308 & 0.0000 \\
\hline Torymidae $^{*}$ & 0.0000 & 0.0000 & 0.0000 & 0.0000 & 0.0000 & 0.0000 & 0.0000 & 0.0033 & 0.0000 & 0.0000 & 0.0000 \\
\hline Charipidae $^{*}$ & 0.0000 & 0.0000 & 0.0000 & 0.0000 & 0.0000 & 0.0000 & 0.0000 & 0.0000 & 0.0000 & 0.0115 & 0.0000 \\
\hline Syrphus sp. & $0.00 \mathrm{~B}$ & $0.00 \mathrm{~B}$ & $0.003 \mathrm{~B}$ & $0.002 \mathrm{~B}$ & $0.001 \mathrm{~B}$ & $0.00 \mathrm{~B}$ & $0.00 \mathrm{~B}$ & $0.00 \mathrm{~B}$ & $0.24 \mathrm{~A}$ & $0.01 \mathrm{~B}$ & $0.003 \mathrm{~B}$ \\
\hline Coccinellidae & $0.03 \mathrm{~B}$ & $0.13 \mathrm{~B}$ & $0.00 \mathrm{~B}$ & $0.02 \mathrm{~B}$ & $0.02 \mathrm{~B}$ & $0.01 \mathrm{~B}$ & $0.07 \mathrm{~B}$ & $0.03 \mathrm{~B}$ & $0.35 \mathrm{~A}$ & $0.00 \mathrm{~B}$ & $0.001 \mathrm{~B}$ \\
\hline Carabidae $^{*}$ & 0.0058 & 0.0217 & 0.0000 & 0.0807 & 0.0225 & 0.0000 & 0.0058 & 0.0276 & 0.2441 & 0.0039 & 0.0407 \\
\hline Aelothripidae & 0.0000 & 0.0059 & 0.0082 & 0.0236 & 0.0145 & 0.0000 & 0.0042 & 0.0257 & 0.0077 & 0.0085 & 0.0189 \\
\hline Orius sp.* & 0.0167 & 0.0106 & 0.0018 & 0.0321 & 0.0040 & 0.0000 & 0.0117 & 0.0071 & 0.0118 & 0.0000 & 0.0014 \\
\hline Chrysoperla sp.* & 0.0000 & 0.0000 & 0.0000 & 0.0000 & 0.0015 & 0.0000 & 0.0042 & 0.0048 & 0.0177 & 0.0000 & 0.0050 \\
\hline Podisus sp.* & 0.0000 & 0.0000 & 0.0000 & 0.0000 & 0.0035 & 0.0000 & 0.0000 & 0.0000 & 0.0000 & 0.0000 & 0.0000 \\
\hline Lebia sp.* & 0.0042 & 0.0000 & 0.0000 & 0.0071 & 0.0000 & 0.0000 & 0.0000 & 0.0000 & 0.0000 & 0.0000 & 0.0000 \\
\hline Geocoris sp.* & 0.0000 & 0.0118 & 0.0000 & 0.0021 & 0.0000 & 0.0000 & 0.0000 & 0.0143 & 0.0018 & 0.0000 & 0.0000 \\
\hline Spiders ${ }^{*}$ & 0.0725 & 0.1729 & 0.0918 & 0.2414 & 0.0700 & 0.1500 & 0.0875 & 0.1919 & 0.1765 & 0.0869 & 0.1271 \\
\hline Crematogaster sp. & $0.28 \mathrm{~A}$ & $0.02 \mathrm{~B}$ & $0.01 \mathrm{~B}$ & $0.22 \mathrm{~A}$ & $0.03 \mathrm{~B}$ & $0.29 \mathrm{~A}$ & $0.04 \mathrm{~B}$ & $0.01 \mathrm{~B}$ & $0.20 \mathrm{~A}$ & $0.02 \mathrm{~B}$ & $0.001 \mathrm{~B}$ \\
\hline
\end{tabular}

Means in a row with the same upper case letter do not differ according to Scott-Knott test $(\mathrm{P}<0.05)$. Not different by ANOVA. 
Table 3. Trichome density per leaf $\left(\mathrm{mm}^{2}\right)$, levels of inorganic $(\%)$ and organic $\left(10^{6} *\right.$ ion $\left.* \mathrm{~s}\right)$ compounds in some crops. Guidoval and Viçosa, Minas Gerais, Brazil.

\begin{tabular}{|c|c|c|c|c|c|c|c|c|c|c|c|}
\hline Plant characteristics & Pumpkin & Eggplant & Kale & Bean & Gilo & $\begin{array}{l}\text { Winter } \\
\text { squash }\end{array}$ & Cucumber & $\begin{array}{l}\text { Sweet } \\
\text { pepper }\end{array}$ & Okra & Cabbage & Tomato \\
\hline Trichomes & $8.77 \mathrm{C}$ & $5.04 \mathrm{D}$ & $0.00 \mathrm{E}$ & $9.38 \mathrm{C}$ & $7.13 \mathrm{C}$ & $14.52 \mathrm{~B}$ & $3.05 \mathrm{D}$ & $0.00 \mathrm{E}$ & $0.30 \mathrm{E}$ & $0.00 \mathrm{E}$ & $19.08 \mathrm{~A}$ \\
\hline Nitrogen & $5.14 \mathrm{~A}$ & $4.32 \mathrm{~B}$ & $4.26 \mathrm{~B}$ & $4.00 \mathrm{~B}$ & $4.74 \mathrm{~A}$ & $4.95 \mathrm{~A}$ & $4.48 \mathrm{~B}$ & $4.53 \mathrm{~B}$ & $4.49 \mathrm{~B}$ & $4.18 \mathrm{~B}$ & $4.28 \mathrm{~B}$ \\
\hline Potassium & $3.62 \mathrm{~B}$ & $4.04 \mathrm{~B}$ & $4.56 \mathrm{~B}$ & $3.62 \mathrm{~B}$ & $4.05 \mathrm{~B}$ & $3.83 \mathrm{~B}$ & $3.16 \mathrm{~B}$ & $7.09 \mathrm{~A}$ & $2.58 \mathrm{~B}$ & $4.97 \mathrm{~B}$ & $4.64 \mathrm{~B}$ \\
\hline Octadecane & $0.00 \mathrm{C}$ & $0.00 \mathrm{C}$ & $0.00 \mathrm{C}$ & $0.00 \mathrm{C}$ & $0.00 \mathrm{C}$ & $0.27 \mathrm{~A}$ & $0.00 \mathrm{C}$ & $0.10 \mathrm{~B}$ & $0.00 \mathrm{C}$ & $0.00 \mathrm{C}$ & $0.00 \mathrm{C}$ \\
\hline$\infty$-Humulene & $1.08 \mathrm{~B}$ & $0.00 \mathrm{C}$ & $0.00 \mathrm{C}$ & $0.00 \mathrm{C}$ & $0.00 \mathrm{C}$ & $0.39 \mathrm{C}$ & $0.91 \mathrm{~B}$ & $0.00 \mathrm{C}$ & $0.00 \mathrm{C}$ & $0.00 \mathrm{C}$ & $1.80 \mathrm{~A}$ \\
\hline Pentacosane & $0.00 \mathrm{~B}$ & $0.00 \mathrm{~B}$ & $0.00 \mathrm{~B}$ & $0.00 \mathrm{~B}$ & $0.00 \mathrm{~B}$ & $0.00 \mathrm{~B}$ & $0.61 \mathrm{~A}$ & $0.00 \mathrm{~B}$ & $0.00 \mathrm{~B}$ & $0.00 \mathrm{~B}$ & $0.00 \mathrm{~B}$ \\
\hline Octacosane & $0.00 \mathrm{D}$ & $0.00 \mathrm{D}$ & $0.00 \mathrm{D}$ & $0.00 \mathrm{D}$ & $0.03 \mathrm{D}$ & $0.17 \mathrm{C}$ & $0.59 \mathrm{~A}$ & $0.31 \mathrm{~B}$ & $0.00 \mathrm{D}$ & $0.00 \mathrm{D}$ & $0.00 \mathrm{D}$ \\
\hline Nonacosane & $0.00 \mathrm{C}$ & $0.38 \mathrm{C}$ & $13.85 \mathrm{~A}$ & $0.12 \mathrm{C}$ & $0.00 \mathrm{C}$ & $0.09 \mathrm{C}$ & $0.41 \mathrm{C}$ & $0.27 \mathrm{C}$ & $0.00 \mathrm{C}$ & 7.57B & $0.00 \mathrm{C}$ \\
\hline Palmitic acid & $0.00 \mathrm{~B}$ & $0.82 \mathrm{~A}$ & $0.00 \mathrm{~B}$ & $0.00 \mathrm{~B}$ & $0.54 \mathrm{~A}$ & $0.00 \mathrm{~B}$ & $0.00 \mathrm{~B}$ & $0.16 \mathrm{~B}$ & $0.46 \mathrm{~A}$ & $0.00 \mathrm{~B}$ & $0.81 \mathrm{~A}$ \\
\hline 11,14,17-Eicosatrienoic methyl ester acid & $2.84 \mathrm{~B}$ & $4.46 \mathrm{~A}$ & $0.00 \mathrm{C}$ & $2.25 \mathrm{~B}$ & $2.99 \mathrm{~B}$ & $0.00 \mathrm{C}$ & $0.00 \mathrm{C}$ & $0.92 \mathrm{C}$ & $2.98 \mathrm{~B}$ & $0.00 \mathrm{C}$ & $0.00 \mathrm{C}$ \\
\hline Hexacosane & $0.00 \mathrm{~B}$ & $0.00 \mathrm{~B}$ & $0.00 \mathrm{~B}$ & $0.00 \mathrm{~B}$ & $0.00 \mathrm{~B}$ & $0.00 \mathrm{~B}$ & $0.00 \mathrm{~B}$ & $0.00 \mathrm{~B}$ & $0.00 \mathrm{~B}$ & $0.00 \mathrm{~B}$ & $0.78 \mathrm{~A}$ \\
\hline Triacontane & 0.00 & 0.00 & 0.00 & 0.00 & 0.00 & 0.00 & 0.00 & 0.00 & 0.00 & 0.00 & 0.16 \\
\hline
\end{tabular}

Means followed by the same upper case letter in the row do not differ according to Scott-Knott test $(\mathrm{P}<0.05)$. *Not different by ANOVA.

Organic compounds with higher levels were $\infty$-humulene in tomato leaves followed by cucumber, pumpkin, and winter squash (Table 3) mainly in high rainfall periods $(\mathrm{r}=0.19, \mathrm{P}=0.0240)$. The 11,14,17-eicosatrienoic methyl ester acid was more frequent in eggplant than in pumpkin followed by common bean, gilo, okra, and sweet pepper (Table 3), which responded positively for $\mathrm{N}$ levels $(\mathrm{r}=0.16, \mathrm{P}=$ $0.0467)$ and negatively for $\mathrm{K}$ levels $(\mathrm{r}=-0.21, \mathrm{P}=0.0155)$. Palmitic acid was found in eggplant, gilo, tomato, okra, and sweet pepper (Table 3) with a trend to higher levels with increases in $\mathrm{N}(\mathrm{r}=0.14, \mathrm{P}=0.0781)$ and $\mathrm{K}(\mathrm{r}=0.15$, $\mathrm{P}=0.0672$ ). Octadecane was higher in winter squash than in sweet pepper and responded positively to $\mathrm{N}$ level $(\mathrm{r}=0.21, \mathrm{P}=0.0157)$. Pentacosane was only detected in cucumber and decreased with $\mathrm{K}(\mathrm{r}=-0.17, \mathrm{P}=0.0382)$. Hexacosane and triacontane were detected in tomato in the warmer months of the year $(r=0.19, \mathrm{P}=0.0327)$. Octacosane was found in higher amounts in cucumber followed by sweet pepper, winter squash, and gilo (Table 3 ), exhibited a positive correlation with $\mathrm{N}$ levels ( $\mathrm{r}=0.21, \mathrm{P}$ $=0.0117)$ and a negative correlation with rainfall $(r=-0.21$, $\mathrm{P}=0.0151)$. A large amount of nonacosane was found in kale followed by cabbage, eggplant, common bean, winter squash, cucumber, and sweet pepper (Table 3 ) with a trend to higher levels when $\mathrm{K}$ increases $(\mathrm{r}=0.15, \mathrm{P}=0.0592)$ and temperature decreases $(\mathrm{r}=-0.19, \mathrm{P}=0.0286)$.

\section{DISCUSSION}

The highest density of $B$. tabaci on cucumber can be due to the higher pentacosane and octacosane levels that had positive correlations with this insect $(r=0.29, P=0.0013$ and $\mathrm{r}=0.22, \mathrm{P}=0.0117$, respectively) and were found to be among the factors that regulated $B$. tabaci density in these plants (Leite et al., 2006b). This suggests that these organic compounds affect $B$. tabaci density and can explain the highest host capacity of cucumber for this insect. Nutritional and morphological features, organic compound levels, and natural enemies do not explain the highest density of $B$. tabaci on eggplant because none of these characteristics are unique for these plants. The highest occurrence of $B$. tabaci in eggplant can be due to planting time because the warmer periods of the year were positively correlated with this pest in most crops $(r=0.49$, $\mathrm{P}=0.0000)$ as found by Leite et al. (2003). This agrees with the survival rate of $88.7,60.2,67.5,46.4$, and $45.8 \%$ of B. argentifolii juveniles on S. melongena, L.esculentum, Ipomoea batatus (L.), C. sativus, and $P$. vulgaris, respectively (Tsai and Wang, 1996). These authors stated that eggplant was the most adequate host for this whitefly. The lowest density of $B$. tabaci on sweet pepper can be on account of higher $\mathrm{K}$ levels $(\mathrm{r}=-0.26, \mathrm{P}=0.0033)$ and the absence of trichomes $(\mathrm{r}=0.25, \mathrm{P}=0.0026)$. Trichomes could hinder B. tabaci location, parasitism, and predation as shown by the positive correlations between Encarsia sp. adults $(\mathrm{r}=0.20 ; \mathrm{P}=0.0058)$ and ladybugs $(\mathrm{r}=0.18$; $\mathrm{P}=0.0094)$ with this pest as reported by Simmons et al. (2002) and Leite et al. (2005a), respectively. Furthermore, the high $\mathrm{K}$ level can reduce the amount of accumulated amino acids, which in turn can reduce the density of sucking insects (Jansson and Ekbom, 2002).

The higher number of individuals of the Brassica spp. specific pest, $B$. brassicae, on kale than on cabbage can be explained by higher nonacosane levels $(\mathrm{r}=0.62, \mathrm{P}=$ $0.0000)$, as well as lower $\mathrm{K}$ levels $(\mathrm{r}=-0.25, \mathrm{P}=0.0045)$ in kale. Potassium is included in the synthesis of RNA polymerase and reduces free amino acid levels in the sap of the plant with populations of B. brassicae (Marschner, $1995)$. This agrees with the high number of $B$. brassicae on kale with a greater nonacosane level (Leite et al., 2005c), but not in cabbage (Leite et al., 2006a). The fact that the high nonacosane level can regulate the $B$. brassicae population on kale can be due to its high level in this plant. The general hypothesis is that wax rarely detains herbivore attack and commonly stimulates it (Woodhead and Chapman, 1986; Leite et al., 2005c). Nonacosane, the main wax component in Brassicaceae (Eigenbrode and Pillai, 1998; Leite et al., 2005c; 2006a) has been associated with plant resistance to water stress (Hull et al., 1975; Leite et al., 2005c), such as the negative correlation observed between nonacosane and temperature. 
High $M$. persicae occurrence on tomato cannot be explained by the parameters evaluated for this plant, but it can be due to a low density of natural enemies because Syrphus sp. $(\mathrm{r}=0.39, \mathrm{P}=0.0000)$ and ladybugs $(\mathrm{r}=0.25$, $\mathrm{P}=0.0006)$ were positively correlated with aphids on the other crops. This agrees with low parasitism on $B$. tabaci by Encarsia pergandiella Howard on tomato and cucumber (Simmons et al., 2002). Higher tomato trichome density can hinder this plant's colonization by natural enemies, which agrees with the population increase of M. persicae the increase of non-glandular trichomes in $S$. gilo described by Leite et al. (2001a). Interaction among several species of insect pests was not observed, but there are reports of competition between $M$. persicae and A. gossypii with a predominance of the latter (Vehrs et al., 1992).

The greatest $A$. gossypii density on okra can be due to the lower trichome density of this plant $(\mathrm{r}=-0.14, \mathrm{P}=$ 0.0548 ) that could facilitate colonization of this pest and increase the number of natural enemies. In spite of the fact that okra had the largest amount of palmitic acid, it was not correlated with A. gossypii. However, this acid was found in okra seed oil (28\%) (Camciuc et al., 1998) as the major triacylglyceride fatty acid in winged forms of Aphis fabae Scopoli (Hemiptera: Aphididae) and was associated with flight energy requirements (Itoyama et al., 2000).

The presence of A. crassivora, a specific legume pest (Gallo et al., 2002), cannot be explained by any of the studied variables. However, the largest populations of this aphid can be related to lower temperatures $(\mathrm{r}=-0.34$, $\mathrm{P}$ $=0.0000)$ as reported for aphid species in other plants (Walker et al., 1984; Nakata, 1995; Picanço et al., 1997; Leite et al., 2001b; 2002c; 2005c).

The occurrence of Empoasca sp. on common bean, an important pest in this crop (Gallo et al., 2002), and on okra, can be due to the 11,14,17-eicosatrienoic methyl ester acid in these plants $(\mathrm{r}=0.34, \mathrm{P}=0.0003)$. Another possible explanation for the density of this pest on these two plants can be their low $\mathrm{K}$ levels, which had a negative correlation with Empoasca sp. $(\mathrm{r}=-0.25, \mathrm{P}=0.0051)$ associated with high densities of the Crematogaster sp. ant, which in turn had a positive correlation with Empoasca $\mathrm{sp} .(\mathrm{r}=0.25, \mathrm{P}=$ 0.0003 ). The $\mathrm{K}$ level of negatively affected Empoasca sp., another sap-sucking pest, possibly for the same reasons discussed for the other two pests. The association between ants and sap-sucking insects is important because it acts negatively on aphid predators and parasitoids (Picanço et al., 1997; Delabie, 2001). This can be one of the factors that explains the low density of natural enemies that had positive correlations with Empoasca sp., Aelothripidae (r $=0.27, \mathrm{P}=0.0003)$, Orius sp. $(\mathrm{r}=0.33, \mathrm{P}=0.0001)$, Lebia sp. $(r=0.15, P=0.0218)$, Encyrtidae and Eulophidae $(r=$ $0.23, \mathrm{P}=0.0011)$ on common bean and okra. The highest presence of Empoasca sp. during medium temperatures $(\mathrm{r}=-0.18, \mathrm{P}=0.0130)$ and lower rainfall $(\mathrm{r}=-0.19, \mathrm{P}=$ 0.0115 ), mainly on okra, agrees with findings by Leite $e t$ al. (2002d) for that insect in eggplant.
The high density of $H$. similis and Epitrix sp. in eggplant can be due to high palmitic acid levels ( $\mathrm{r}=$ $0.16, \mathrm{P}=0.0457$ and $\mathrm{r}=0.30, \mathrm{P}=0.0011$, respectively), $11,14,17$-eicosatrienoic methyl ester acid $(\mathrm{r}=0.33, \mathrm{P}=$ 0.0002 and $\mathrm{r}=0.32, \mathrm{P}=0.0005$, respectively), and to the low $\mathrm{N}$ level in the leaves $(\mathrm{r}=-0.24, \mathrm{P}=0.0061)$ of this plant. On the other hand, the great attack of Colaspis sp. on eggplant can be due to its high 11,14,17-eicosatrienoic methyl ester acid level $(\mathrm{r}=0.24, \mathrm{P}=0.0078)$. $H$. similis and Epitrix sp. were more frequent, mainly on eggplant, during medium $(\mathrm{r}=-0.32, \mathrm{P}=0.0000)$ and hotter $(\mathrm{r}=$ $0.14, \mathrm{P}=0.0418$ ) temperature periods, respectively (Leite et al., 2002d).

The presence of T. palmi, only on eggplant, can be due to the fact that this plant has one of the lowest $\mathrm{K}$ levels and trichome density that negatively affected this pest $(\mathrm{r}=$ $-0.26, \mathrm{P}=0.0035$ and $\mathrm{r}=-0.12, \mathrm{P}=0.0975$, respectively).

The fact that $T$. tabaci only attacked kale, cabbage, and common bean cannot be explained by any of the studied variables. Frankliniella spp. is the most common thrips species in Brazil and its high occurrence in cucumber can be on account of high pentacosane $(r=0.48, P=0.0001)$ and octacosane $(\mathrm{r}=0.18, \mathrm{P}=0.0338)$ levels in its leaves and where individuals of this pest were found during periods of higher temperature $(r=0.20, P=0.0062)$. A temperature decrease during the development period of thrips can increase its population (Gonçalves, 1997; Leite et al., 2002a; 2006a). Pentacosane and Frankliniella schulzei (Trybon) (Thysanoptera: Thripidae) were positively correlated in cucumber (Leite et al., 2005b). The Scelionidae $(r=0.30, P=0.0001)$ and Eulophidae $(r=0.14, P=0.0367)$ species, which are considered the most important natural enemies of thrips (Venzon et al., 1999; Funderburk et al., 2000; Tagashira and Hirose, 2001), exhibited a positive correlation with Frankliniella sp.

Sistena sp. was more frequent in winter squash, probably because of its high octadecane level $(\mathrm{r}=0.64$, $\mathrm{P}=0.0001)$, trichome density $(\mathrm{r}=0.18, \mathrm{P}=0.0223)$, and the presence of the Crematogaster $\mathrm{sp}$. ant $(\mathrm{r}=0.20$, $\mathrm{P}=0.0044$ ) on the leaves. None of the studied variables explain D. speciosa damage on the plants probably because this pest is polyphagous (Gallo et al., 2002) adapted to diverse hosts; $D$. speciosa was detected more in periods of medium temperatures $(\mathrm{r}=-0.17, \mathrm{P}=0.0151)$. The monophagy of T. absoluta on tomato (Gallo et al., 2002) can be explained by the presence of $\infty$-humulene $(\mathrm{r}$ $=0.42, \mathrm{P}=0.0000)$ and hexacosane $(\mathrm{r}=0.58, \mathrm{P}=0.0000)$ in this plant, which were positively correlated with this moth.

\section{CONCLUSIONS}

Some compounds seem to be important for plant selection by pests, such as pentacosane and octacosane for $B$. tabaci and Frankliniella sp.; nonacosane for B. brassicae; 
octadecane for Sistena sp.; palmitic acid for A. gossypii, H. similis, and Epitrix sp.; 11,14,17 eicosatrienoic methyl ester acid for $H$. similis and Epitrix sp.; $\infty$-humulene and hexacosane for T. absoluta. Furthermore, the increase of plant $\mathrm{K}$ levels negatively affects sap-sucking pests and explains the preference for certain host plants. Trichomes are not important for the preference of host plants, but they can negatively affect natural enemies and result in a pest population increase. However, it should be emphasized that these trichomes were non-glandular.

All of the studied plants are hosts for B. tabaci, so they should be avoided. However, kale or cabbage can be used because B. tabaci had a low density on Brassica spp. Furthermore, the use of kale or cabbage is important because $B$. brassicae and T. tabaci do not attack other plants and Brassica spp. had low densities of these insects. Cultivating plants of different families, one Brassicae (kale or cabbage) and another in the crop rotation can reduce insect pest populations in the field.

\section{Capacidad de alojamiento de plantas hortícolas para} plagas de insectos en Brasil. Factores tales como la fertilización, aleloquímicos, tricomas, el clima y los enemigos naturales pueden influir en las poblaciones de plagas. Por lo tanto, es necesario comprender los factores que predisponen a las especies vegetales a las plagas y el papel de policultivos, rotación de cultivos y las plantas vecinas. El objetivo de este trabajo fue estudiar la capacidad hospedera de Abelmoschus esculentus (L.), Brassica oleracea L. vars. acephala and capitata, Capsicum annuum L., Cucurbita moschata (Duchesne), Cucurbita maxima Duchesne, Cucumis sativus L., Lycopersicon esculentum Mill., Solanum gilo Raddi, Solanum melongena L. y Phaseolus vulgaris L. a insectos plaga. La mayor densidad de adultos de Bemisia tabaci (Genn.) en $C$. sativus puede deberse al mayor contenido de pentacosano y octacosano en estas plantas. La aparición de Brevicoryne brassicae (L.) sólo en Brassica spp. puede ser debida a la nonacosano de estas plantas. La baja densidad de tricomas y mayor cantidad de ácido palmítico puede explicar el mayor daño por Aphis gossypii Glover en A. esculentum. Empoasca sp. fue más frecuente en $P$. vulgaris, seguido por A.esculentum, las plantas con menor contenido de K. Solanum melongena fue más atacada por Hortensia similis (Walter) y Epitrix sp., tal vez debido al aumento de las concentraciones de ácido palmítico y el éster metílico 11,14,17-eicosatrienoico en sus hojas. Frankliniella sp. presentan mayor daño en C. sativus, probablemente por el mayor contenido de pentacosano y octacosane en sus hojas. Sistena sp. fue más frecuente en C. maxima que tenían los mayores niveles de octadecano y densidad de tricomas. La presencia de $\infty$-humuleno y hexacosane podría explicar el daño por Tuta absoluta (Meyrick) en L. esculentum.

Palabras clave: tricomas, aleloquímicos, nitrógeno, potasio, insectos.

\section{LITERATURE CITED}

Altieri, M.A., E.N. Silva, and C.I. Nicholls. 2003. O papel da biodiversidade no manejo de pragas. 226 p. Holos, Ribeirão Preto, Brazil.

Brunner, P.C., E.K. Chatzivassiliou, N.I. Katis, and J.E. Frey. 2004 Host-associated genetic differentiation in Thrips tabaci (Insecta; Thysanoptera), as determined from mtDNA sequence data. Heredity 93:364-370.

Camciuc, M., M. Deplagne, G. Vilarem, and A. Gaset. 1998. Okra - Abelmoschus esculentus L. (Moench.) a crop with economic potential for set aside acreage in France. Industrial Crops and Products 7:257-264.

Chau, A., M. Heinz, and F.T. Davies Jr. 2005. Influences of fertilization on Aphis gossypii and insecticide usage. Journal of Applied Entomology 129:89-97.

Delabie, J.H.C. 2001. Trophobiosis between Formicidae and Hemiptera (Sternorrhyncha and Auchenorrhyncha): an overview. Neotropical Entomology 30:501-516.

Eigenbrode, S.D., and S.K. Pillai. 1998. Neonate Plutella xylostella responses to surface wax components of a resistant cabbage (Brassica oleracea). Journal of Chemical Ecology 24:1611-1627.

Filgueira, F.A.R. 2000. Novo manual de olericultura. 402 p. Universidade Federal de Viçosa, Viçosa, Brasil.

Funderburk J., J. Stavisky, and S. Olson. 2000. Predation of Frankliniella occidentalis (Thysanoptera: Thripidae) in field peppers by Orius insidiosus (Hemiptera: Anthocoridae). Environmental Entomology 29:376-382.

Gallo, D., O. Nakano, S. Silveira Neto, R.P.L. Carvalho, G.C. Batista, E. Berti Filho, et al. 2002. Manual de entomologia agrícola. 920 p. Fundação de Estudos Agrários Luiz de Queiroz, Piracicaba, Brasil.

Gonçalves, P.A.S. 1997. Flutuação populacional de tripes, Thrips tabaci Lind., em cebola em Ituporanga, Santa Catarina. Anais da Sociedade Entomológica do Brasil 26:365-369.

Horowitz, A.R. 1993. Control strategy for the sweetpotato whitefly, Bemisia tabaci, late in the cotton-growing season. Phytoparasitica 21:281-291.

Hull, H.M., H.L. Morton, and J.R. Wharrie. 1975. Environmental influences on cuticle development and resultant foliar penetration. Botanical Review 41:421-452.

Itoyama, K., S. Tojo, T. Yanagita, and J. Hardie. 2000. Lipid composition in long-day and short-day forms of the black bean aphid, Aphis fabae. Journal of Insect Physiology 46:119-125.

Jansson, J., and B. Ekbom. 2002. The effect of different plant nutrient regimes on the aphid Macrosiphum euphorbiae growing on petunia. Entomologia Experimentalis et Applicata 104:109116.

Leite, G.L.D., G.N. Jham, M. Picanço, A.A. Azevedo, and M.D. Moreira. 2011. Factors influencing insect attack on the commonbean. Trends in Entomology. In press.

Leite, G.L.D., M. Picanço, A.A. Azevedo, and M.R. Gusmão. 2002c. Fatores que influenciam as populações de artrópodes em moranga (Cucurbita maxima var. IAC-100). Agronomia Lusitana 50:153159.

Leite, G.L.D., M. Picanço, A.A. Azevedo, and M.R. Gusmão. 2001a. Factores que influenciam o ataque de pulgões e de tripes em jiloeiro (Solanum gilo var. gigante portuguesa). Agronomia Lusitana 49:181-195.

Leite, G.L.D., M. Picanço, R.N.C. Guedes, and M.D. Moreira. 2003. Factors affecting attack rate of whitefly on the eggplant. Pesquisa Agropecuária Brasileira 38:545-549.

Leite, G.L.D., M. Picanço, R.N.C. Guedes, and, C.C. Ecole. 2006b. Factors affecting the attack rate of Bemisia tabaci on cucumber. Pesquisa Agropecuária Brasileira 41:1241-1245.

Leite, G.L.D., M. Picanço, G.N. Jham, and C.C. Ecole. 2002a. Effect of leaf characteristics, natural enemies and climatic conditions on the intensities of Myzus persicae and Frankliniella schulzei attacks on Lycopersicon esculentum. Arquivos do Instituto Biológico 69:71-82. 
Leite, G.L.D., M. Picanço, G.N. Jham, and M.R. Gusmão. 2002b. Fatores naturais que influenciam o ataque da mosca-branca em pimentão. Pesquisa Agropecuária Brasileira 37:1195-1200.

Leite, G.L.D., M. Picanço, G.N. Jham, and F. Marquini. 2005b. Factors affecting the attack rate of Frankliniella schulzei on cucumber. Trends in Entomology 4:67-69.

Leite, G.L.D., M. Picanço, G.N. Jham, and, M.D. Moreira. 2005a. Whitefly population dynamics in okra plantations. Pesquisa Agropecuária Brasileira 40:19-25.

Leite, G.L.D., M. Picanço, G.N. Jham, and M.D. Moreira. 2005c. Bemisia tabaci, Brevicoryne brassicae and Thrips tabaci abundance on Brassica oleracea var. acephala. Pesquisa Agropecuária Brasileira 40:197-202.

Leite, G.L.D., M. Picanço, G.N. Jham, and M.D. Moreira. 2006a. Whitefly, aphids and thrips attack on cabbage. Pesquisa Agropecuária Brasileira 41:1469-1475.

Leite, G.L.D., M. Picanço, J.C. Zanuncio, and M.D. Moreira. 2001b. Factores que influenciam as populações de artrópodes em abóbora (Cucurbita moschata var. menina brasileira). Agronomia Lusitana 49:163-179.

Leite, G.L.D., M. Picanço, J.C. Zanuncio, and F. Marquini. 2002d. Factors affecting the attack rates of Epitrix sp. and Colaspis spp. (Coleoptera: Chrysomelidae), and Empoasca sp. and Hortensia similis (Homoptera: Cicadellidae) on eggplant (Solanum melongena). Agronomia Lusitana 50:81-88.

Marschner, H. 1995. Mineral nutrition of higher plants. 889 p. Academic Press, London, UK.

Men, X.Y., F. Ge, E.N. Yardim, and M.N. Parajulee. 2004. Evaluation of winter wheat as a potential relay crop for enhancing biological control of cotton aphids in seedling cotton. BioControl 49:701714.

Miranda, M.M.M., M. Picanço, G.L.D. Leite, J.C. Zanuncio, and P. Clercq. 1998. Sampling and non-action levels for predators and parasitoids of virus vectors and leaf miners of tomato plants in Brazil. Mededelingen Faculteit Landbouwwetenschappen Universiteit Gent 63:519-523.

Nakata, T. 1995. Population fluctuations of aphids and their natural enemies on potato in Hokkaido, Japan. Applied Entomology and Zoology 30:129-138.

Picanço, M., V.W.D. Casali, I.R. Oliveira, and G.L.D. Leite. 1997. Homópteros associados ao jiloeiro. Pesquisa Agropecuária Brasileira 32:451-456.
Rhainds, M., and R.H. Messing. 2005. Spatial and temporal density dependence in a population of melon aphid, Aphis gossypii Glover (Homoptera: Aphididae), on established and sentinel taro plants. Applied Entomology and Zoology 40:273-282.

Satar, S., U. Kersting, and N. Uygun. 2005. Effect of temperature on development and fecundity of Aphis gossypii Glover (Homoptera: Aphididae) on cucumber. Journal of Pest Science 78:133-137.

Sechser, B., B. Reber, and F. Bourgeois. 2002. Pymetrozine: selectivity spectrum to beneficial arthropods and fitness for integrated pest management. Journal of Pest Science 75:72-77.

Simmons, A.M., S. Abd-Rabou, and G.S. Mccutcheon. 2002. Incidence of parasitoids and parasitism of Bemisia tabaci (Homoptera: Aleyrodidae) in numerous crops. Environmental Entomology 31:1030-1036.

Slosser, J.E., M.N. Parajulee, D.L. Hendrix, T.J. Henneberry, and W.E. Pinchak. 2004. Cotton aphid (Homoptera: Aphididae) abundance in relation to cotton leaf sugars. Environmental Entomology 33:690-699.

Tagashira, E., and Y. Hirose. 2001. Development and reproduction of Ceranisus menes (Hymenoptera: Eulophidae), a larval parasitoid of thrips: effects of two host species, Frankliniella intonsa and Thrips palmi (Thysanoptera: Thripidae). Applied Entomology and Zoology 36:237-241.

Tsai, J.H., and K.H. Wang. 1996. Development and reproduction of Bemisia argentifolii (Homoptera: Aleyrodidae) on five host plants. Environmental Entomology 25:810-816.

Vehrs, S.L.C., G.P. Walker, and M.P. Parrella. 1992. Comparison of population-growth rate and within-plant distribution between Aphis gossypii and Myzus persicae (Homoptera, Aphididae) reared on potted chrysanthemums. Journal of Economic Entomology 85:799-807.

Venzon, M., A. Janssen, and M.W. Sabelis. 1999. Attraction of a generalist predator towards herbivore-infested plants. Entomologia Experimentalis et Applicata 93:305-314.

Walker, G.P., L.R. Nautl, and D.E. Simonet. 1984. Natural mortality factors acting on potato aphid (Macrosiphum euphorbiae) populations in processing-tomato fields in Ohio. Environmental Entomology 13:724-732.

Woodhead, S., and R.F. Chapman. 1986. Insect behaviour and the chemistry of plant surface waxes. p. 123-135. In Juniper B.E., and Southwood T.R.E. (eds.) Insect and the plant surface. Edward Arnold, London, UK. 